\begin{tabular}{lcl}
\hline Bentham open & The Open Materials Science Journal \\
CrossMark & Content list available at: www.benthamopen.com/TOMSJ/ \\
\hline
\end{tabular}

RESEARCH ARTICLE

\title{
Corrosion Behavior of Plasma Nitrided SS316L Biomaterial
}

\author{
Ratna Kartikasari ${ }^{1, *}$, Sutrisna ${ }^{1}$ and Ihwanul Aziz ${ }^{2}$ \\ I"Nasional" College of Technology Jl. Babarsari No. 1 Caturtunggal, Depok, Sleman, Yogyakarta, Indonesia 55281 \\ ${ }^{2}$ PTAPB BATAN Yogyakarta, 55281, Indonesia
}

Received: November 23, 2016

Revised: April 28, 2017

Accepted: May 19, 2017

\begin{abstract}
:
Objective:

This research aims to determine corrosion behavior of SS316L biomaterial metals after plasma nitriding process.

Methods:

The plasma nitriding process on the surface of SS316L was performed at $350 \mathrm{oC}, 400 \mathrm{oC}, 450 \mathrm{oC}, 500 \mathrm{oC}, 550 \mathrm{oC}$ and $1.8 \mathrm{mbar}$ nitrogen gas pressure for 3 hours. The surface Nitrogen concentration level distribution from the surface was examined using Energy Dispersive X-ray Spectroscopy, the phases formed after nitriding process were determined using X-ray Diffraction. The corrosion resistance was investigated using three-electrode cell polarization method.
\end{abstract}

Result:

The results showed that the percentage of nitrogen concentration atoms on the surface of the SS316L after plasma nitriding process was in range of $7.61-21.73 \%$, in which the highest number $21.73 \%$ occurred at $500 \mathrm{oC}$. Metal nitride formed on the surface of SS316L for all temperature variations are $\mathrm{Fe} 4 \mathrm{~N}, \mathrm{CrN}$ and $\beta-\mathrm{Cr} 2 \mathrm{~N}$ phases were formed after nitriding process. Optimum corrosion resistance $(8.21 \times 10-4 \mathrm{~mm} / \mathrm{yr})$ occurs at $350 \mathrm{oC}$.

Keywords: Plasma nitriding, SS316L, Biomaterials, Corrosion resistance, Nitrogen, $\mathrm{Fe}_{4} \mathrm{~N}$.

\section{INTRODUCTION}

Biomaterials are materials that have already been used in medical devices or been in contact with biological system and they do not negatively affect the living organism and its components [1]. Biomaterials are one of the modified natural or synthetic materials, which find application in a wide spectrum of medical and dental implants and prosthesis for repair, augmentation or replacement of natural tissues. Some of the clinical uses of biomaterials are total joint replacement, venal grafts, heart valves, cranial plates, Harrington rods, dummy tendon and ligament, bone spaces filler and disc cress repair [2]. To relieve pain and increase ease of movement in the joint are the clinical objective of biomaterials [3], while the engineering objective is to impart minimal psychological stress to the stay bone system so that the wholeness and the functionality of the bone and prosthetic materials are maintained over for a long service life. Thus, materials suitable for service implantation are those that are well tolerated by the body and can withstand cyclic loading in the aggressive environment.

The main problem that often arises in the orthopedic device transplant is the interaction between the surface of orthopedic devices with the surrounding environment and the surface of physiological orthopedic device itself. Such interactions result in the occurrence of corrosion and/or wear and tear that can lead to graft failure and/or a bad effect on a patient that result in rejection by the body tissue around it. The basic requirements in selecting biomaterials

\footnotetext{
* Address correspondence to this author at the "Nasional" College of Technology Jl. Babarsari No. 1 Caturtunggal, Depok, Sleman, Yogyakarta, Indonesia 55281; E-mail: ratna@sttnas.ac.id
} 
are biocompatibility, nontoxicity, resistance to corrosion and wear so they can withstand repeated load in corrosive body tissue [4].

The metal based biomaterials are often used for load bearing such as bolt, plate, connection, or knee joints, the stalk of the femur and others $[5,6]$. There are three types of metal alloys which are often used for orthopedic devices: stainless steel, titanium and its alloys, and cobalt-chromium-based alloy. Type of metal used in a biomedical field depends on the specific implant applications. Austenitic stainless steel, especially SS 316L, is a biomaterial metal that is widely used for the fabrication of orthopedic graft devices or prosthetic because they are cheaper and the fabrication is easier to perform than the Co-Cr alloys or Ti and its alloys. 316L SS is still the most used alloy in all implants division ranging from cardiovascular to otorhinology [7].

Stainless steel has a good biocompatibility [8]. The addition of nickel on austenitic structure can potentially release $\mathrm{Ni} 2+, \mathrm{Cr} 3+$ and $\mathrm{Cr} 6+$ in a stainless steel body which is limited to orthopedic devices [9]. Ninety percent of the failure of the graft orthopedic transplant or metal based prosthetic, especially SS 316L stainless steel is caused by corrosion attack due to the interaction with body fluids and wear which occurs due to holding burden of friction in the joints [10]. Metallic biomaterials are used due to their inertness and structural functions. They do not have bio functionalities like blood compatibility, bone conductivity and bioactivity. Therefore, surface modifications are required [11]. A method is required for surface treatment which is easy to use and inexpensive to improve the mechanical properties, corrosion resistance and biocompatibility of SS316L as metallic biomaterials [12].

Recently, many research conducted to improve surface characteristic of metals or alloys used in biomedical system [7]. To avoid the decline corrosion resistance of stainless steels in conventional nitriding (precipitation of CrN), lowtemperature nitriding techniques like ion implantation, plasma immersion ion implantation and low-temperature plasma nitriding were developed [13 - 16]. This research aims to determine the effect of plasma nitriding process to corrosion behavior of biomaterial SS316L.

\section{METHOD}

The SS 316L stainless steel plate with $2 \mathrm{~mm}$ thickness was cut into $1 \mathrm{~cm}$ x $1 \mathrm{~cm}$ for nitriding process. Furthermore, the specimen surfaces were smoothened using a polishing machine with 400, 800, 1000 and 2000 mesh sandpaper and polished using diamond paste. They were cleaned with ultrasonic cleaner to be free of dirt and grease which then followed by drying surfaces using hair dryer. Nitriding process was performed using a plasma nitriding equipment which comprises of a vacuum vessel made of metal. It was equipped with a vacuum system, nitrogen gas input system, high-voltage DC systems 300-1200 volts and a temperature regulator. Nitriding process was carried out at temperature of $350,400,450,500$ and $550^{\circ} \mathrm{C}$, pressure of 1.8 mbar within 3 hours. The $\mathrm{N}$ content in the surface of SS316L was examined by JEOLJSM 6510 LA EDS equipment using CuK $\alpha$ radiation, phases were examined using Rigaku Multiflex $2 \mathrm{kw}$ XRD equipment and corrosion resistance was examined using PGS-201T potensiostat corrosion testing within Hanks solution media.

\section{RESULTS AND DISCUSSION}

Biomaterial SS316L N content in the surface of SS316L before and after nitriding process was tested using EDS techniques. The results of the composition test showed that the SS $316 \mathrm{~L}$ contains $69.80 \mathrm{~atm} \% \mathrm{Fe}, 18.98 \mathrm{~atm} \% \mathrm{Cr}$, Ni $9.88 \mathrm{~atm} \%, 1.34 \mathrm{~atm} \%$ Mo, while the element of nitrogen is not found. Fig. (1) shows the EDS test result of SS 316L.

The EDS test results on the surface of SS316L after nitriding process (Fig. 2) indicate the presence of a thin layer of iron nitride and the percentage of nitrogen were deposited on the surface of SS 316L. The percentage of nitrogen on the surface of SS 316L are influenced by temperature plasma nitriding process. Rising temperature of nitriding process causes larger distance between the atoms of the specimen so that the possibility of nitrogen atoms diffusion into the crystal Fe system becomes easier. Fig. (3) displays the surface of SS316L after nitriding process at $350^{\circ} \mathrm{C}, 400^{\circ} \mathrm{C}$, $450^{\circ} \mathrm{C}, 500^{\circ} \mathrm{C}$ and $550^{\circ} \mathrm{C}$, containing nitrogen atom of $7.61 \mathrm{~atm} \%, 10.73 \mathrm{~atm} \%, 20.46 \mathrm{~atm} \%, 21.73 \mathrm{~atm} \%$ and 15.60 atm $\%$ respectively. 


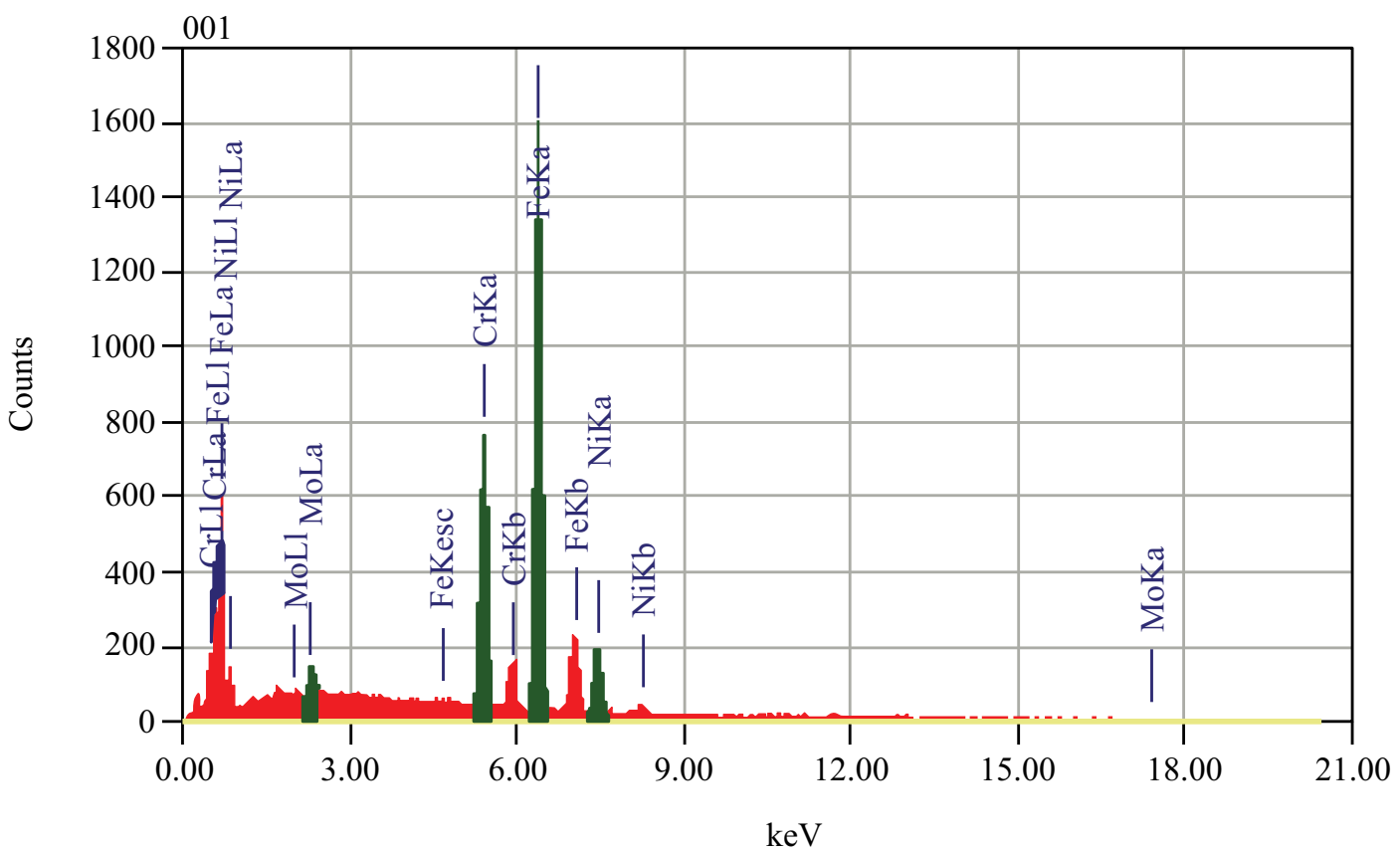

Fig. (1). The EDS micrograph of standard SS316L before plasma nitriding.

The nitrogen atom percentage increased at 350 to $500^{\circ} \mathrm{C}$ evidently as performed by Souza [17] and Oliviera [15], whereas at $550^{\circ} \mathrm{C}$ percentage of nitrogen atom decreased. The decline in the percentage of nitrogen atom was resulted by nitriding temperature which constitutes a function of the depth of nitrogen atoms entry into the specimen. When the nitriding temperature was raised to $500^{\circ} \mathrm{C}$, then the distance between atoms specimen became larger so that the possibility of nitrogen atoms diffusion to form an iron nitride layer on the surface of the specimen was easier.

Furthermore, if the nitriding temperature was raised above $500^{\circ} \mathrm{C}$, the distance between atoms of specimen became greater. So, the nitrogen atoms in the specimen surface diffused deeper below the surface of the snippet, causing the percentage of nitrogen atoms on the surface of the specimen decreased. Based on the $\mathrm{Fe}-\mathrm{N}$ phase diagram, nitriding process at the nitriding temperature of $350^{\circ} \mathrm{C}$ to $550^{\circ} \mathrm{C}$ with a percentage of nitrogen atoms between $7 \%$ to $21 \%$ resulted Fe $4 \mathrm{~N}$ iron nitride phase (Fig. 3). The percentage of nitrogen atoms which are deposited on the surface of the specimen determines the percentage $\mathrm{Fe} 4 \mathrm{~N}$ phase formed on the surface of the specimen.

The Fe nitride layer on SS $316 \mathrm{~L}$ surfaces was examined using the XRD technique. Figs. $(\mathbf{4}, \mathbf{5})$ shows diffraction pattern of SS316 before and after nitriding process at $350^{\circ} \mathrm{C}, 400^{\circ} \mathrm{C}, 450^{\circ} \mathrm{C}, 500^{\circ} \mathrm{C}$ and $550^{\circ} \mathrm{C}, 1.8 \mathrm{mbar}$ nitrogen gas pressure and 3 hours nitriding time. Figs. $(4,5)$ shows that before nitriding process, Fe nitride layer was not observed on diffraction pattern footage of SS316L while after nitriding process $\mathrm{Fe}$ nitride layer was formed and $\mathrm{Fe}_{4} \mathrm{~N}, \mathrm{CrN}$ and $\beta$ $\mathrm{Cr}_{2} \mathrm{~N}$ peaks were produced. Figs. $(4,5)$ shows that each snippet generated $\mathrm{Fe}_{4} \mathrm{~N}$ phase. The difference is the percentage of $\mathrm{Fe}_{4} \mathrm{~N}$ which was formed on each snippet. The $\mathrm{Fe}_{4} \mathrm{~N}$ phase was formed at $450^{\circ} \mathrm{C}-680^{\circ} \mathrm{C}$ and $20 \mathrm{~atm} \%$ nitrogen. The $\mathrm{Fe}_{4} \mathrm{~N}$-iron nitride layer increases wear resistance and hardness footage of SS $316 \mathrm{~L}$, while the formation of a chromium nitride layer and $\beta-\mathrm{Cr}_{2} \mathrm{~N}$ causes chromium deficiency. This leads to a deficiency of $\mathrm{Cr}$ oxide that serves as passive steady layer on the surface of the footage from corrosive environments. Therefore, the formation of chromium nitride layer can lead to a reduction in corrosion resistance 18].

One of the important properties of metallic biomaterials which are used for prosthetic or orthopedic graft device is corrosion resistance. Footage corrosion rate was tested using a potentiostat PGS-201T by dissolving materials in the Hank solution. The accuracy of determining the current intensity of corrosion $\left(\mathrm{I}_{\mathrm{Cor}}\right)$ was necessary, because the $\mathrm{I}_{\text {cor }}$ is directly proportional to the corrosion rate magnitude and inversely proportional to the density and extensive footage. The results of SS316 corrosion tests before plasma nitriding process can be seen in Fig. (5), and after plasma nitriding at $350^{\circ} \mathrm{C}, 400^{\circ} \mathrm{C}, 450^{\circ} \mathrm{C}, 500^{\circ} \mathrm{C}$, and $550^{\circ} \mathrm{C}$ for 3 hours, can be seen in Fig. (6). 

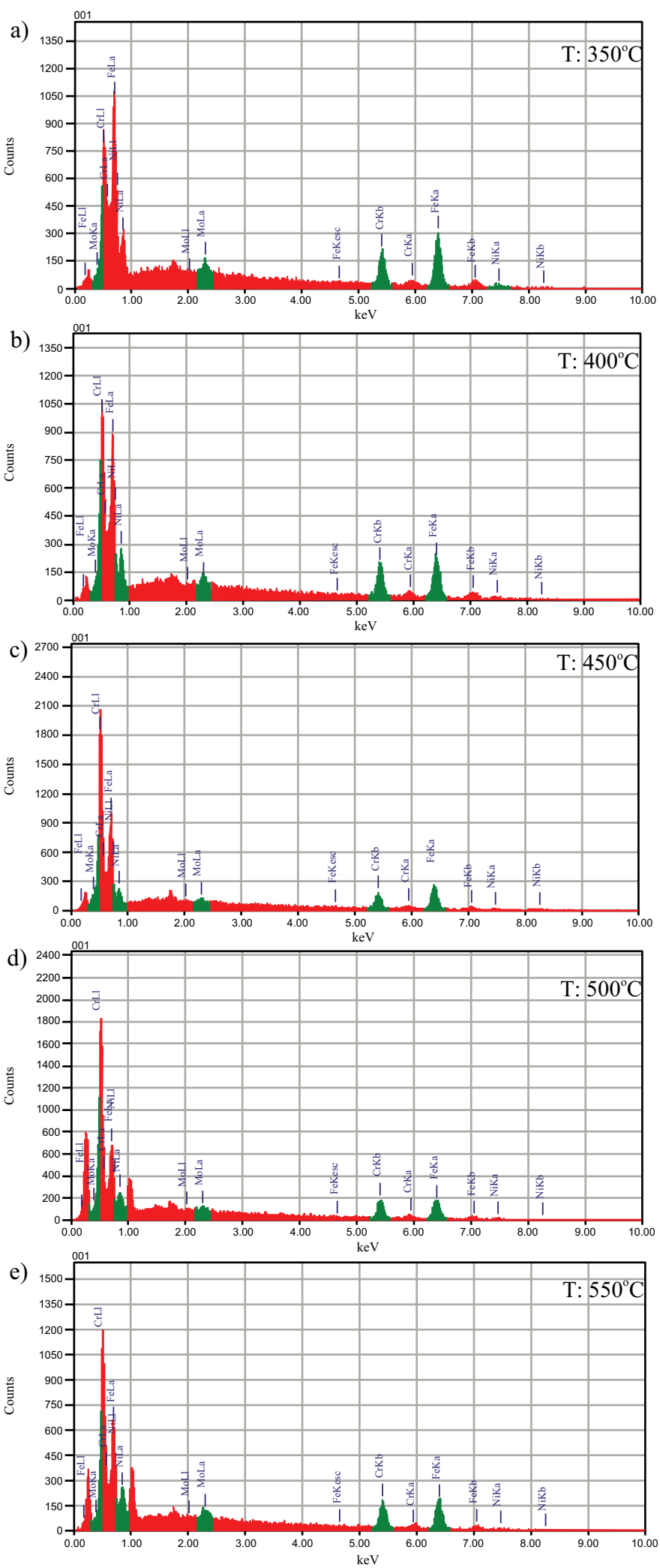

Fig. (2). The EDS micrograph of SS316L after plasma nitriding process. 


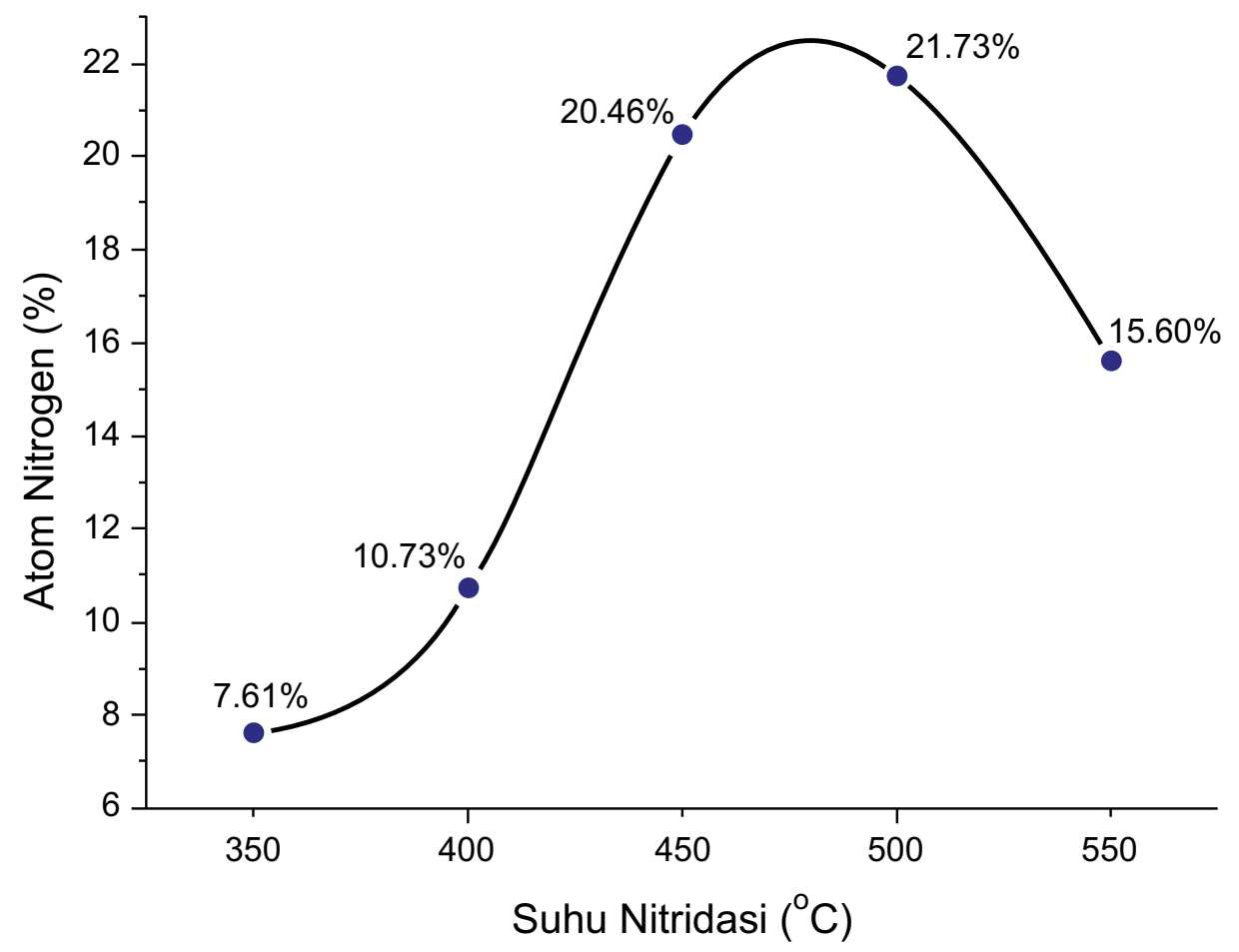

Fig. (3). Nitrogen concentration (at.\%) vs nitriding temperature of SS 316L stainless steel.

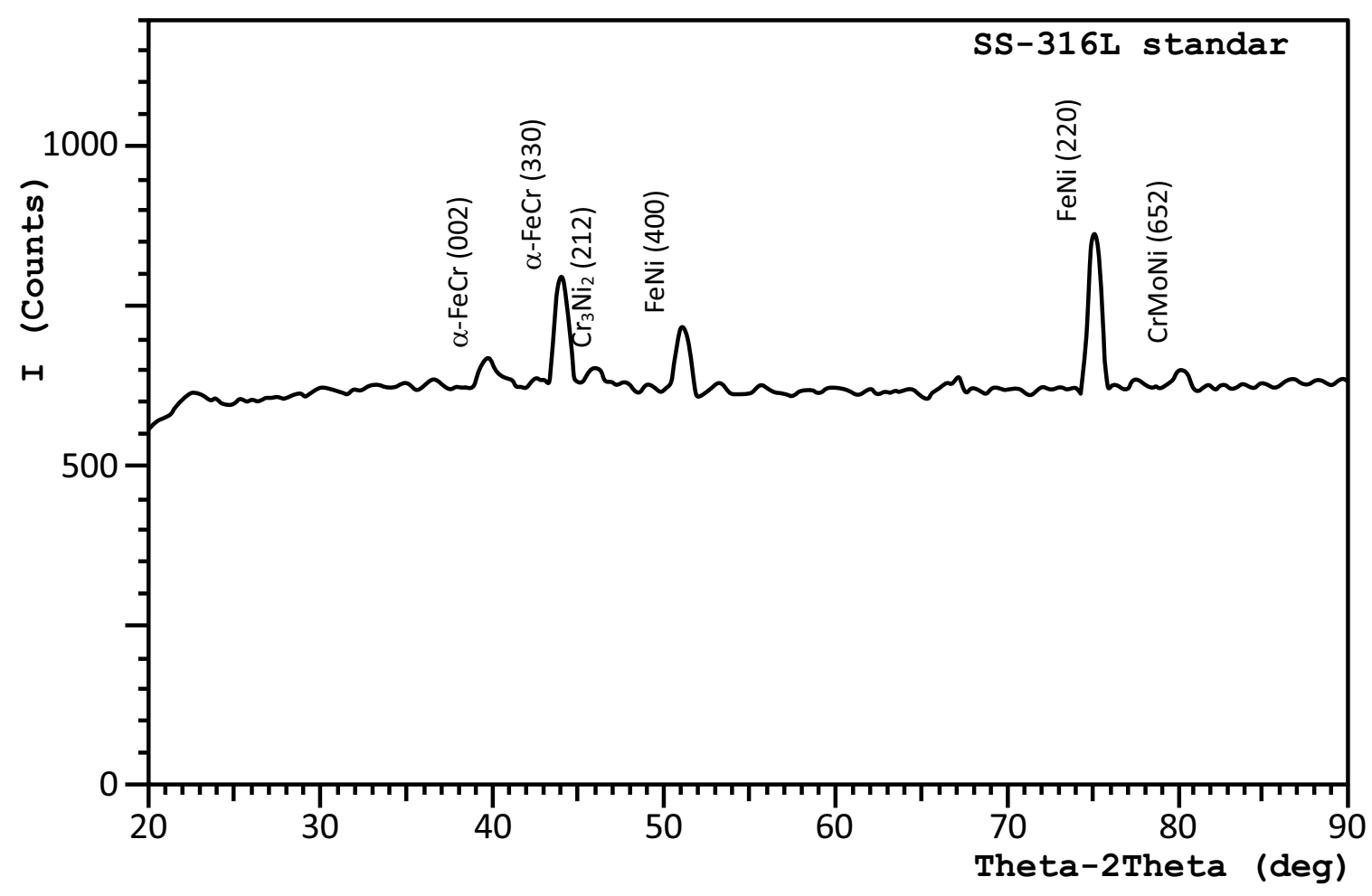

Fig. (4a). The diffraction pattern of standard SS316L before plasma nitriding. 

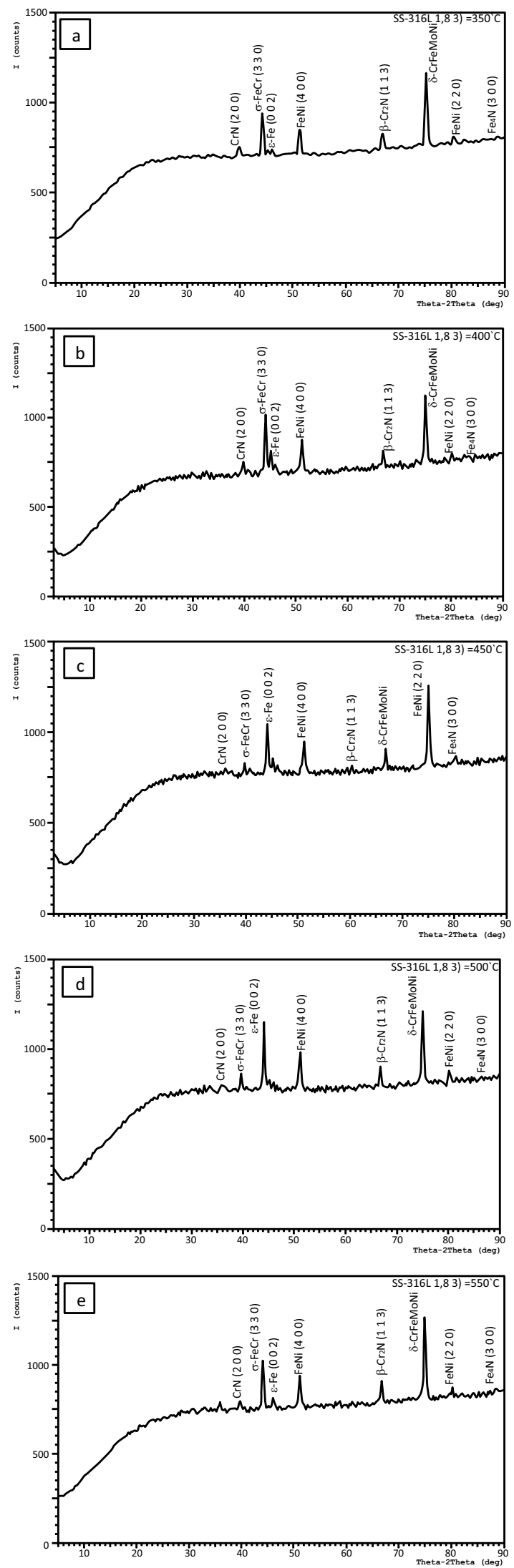

Fig. (4b). The diffraction pattern of SS 316L after nitriding process. 


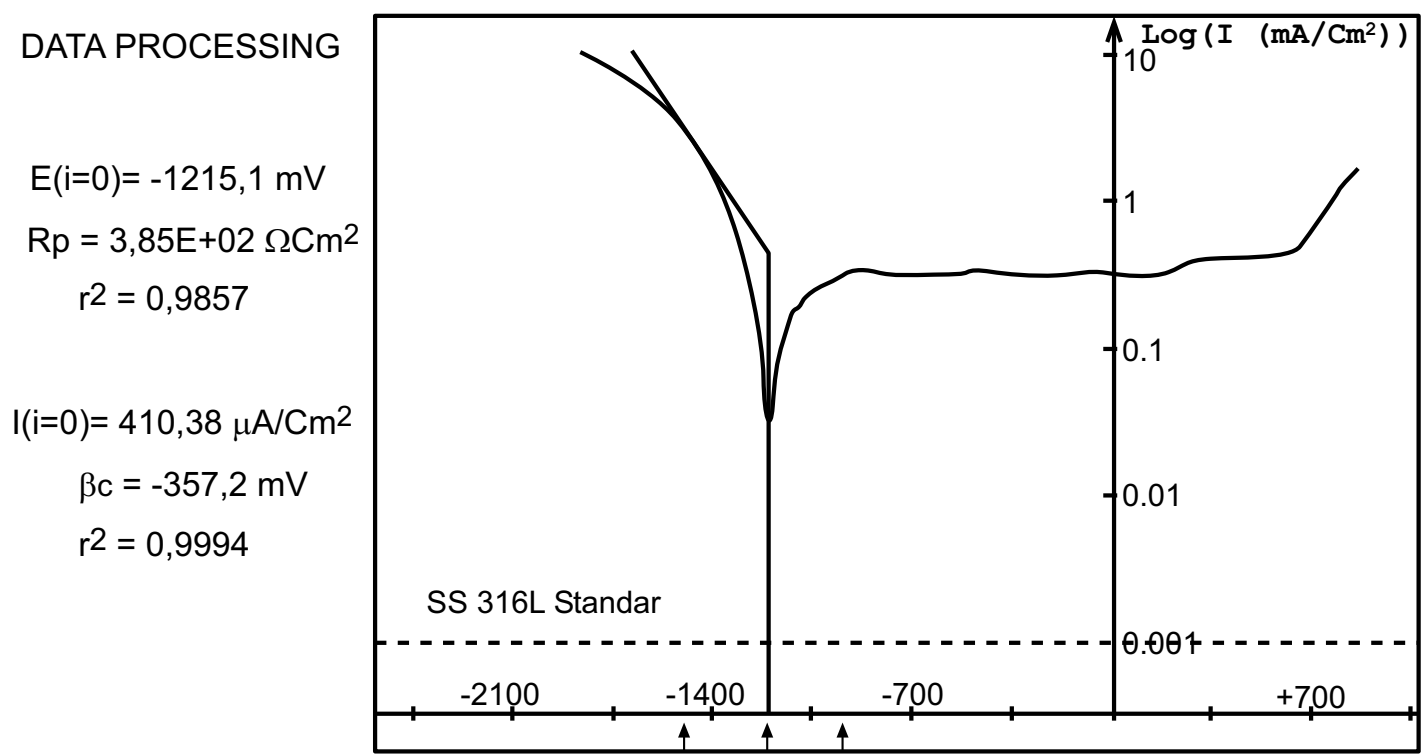

Fig. (5). Micrograph log intensity vs. potential corrosion current density of SS316L before nitriding process.

The corrosion resistance of SS316L stainless steel was tested using an electrochemical method with the polarization resistance technique (using a potentiostat PGS-201T). The corrosion resistance can be seen from the corrosion current density during the test. The greater the current density of corosion, the greater the probability of corrosion on the speciment, and vice versa. In order to obtain a sample which is resistant to corrosion, parameter of nitriding process is associated with pressure, temperature, and duration of the nitriding process. In this study, nitriding was performed at 1.8 mbar for 3 hours by temperature variations of $350^{\circ} \mathrm{C}, 400^{\circ} \mathrm{C}, 450^{\circ} \mathrm{C}, 500^{\circ} \mathrm{C}$, and $550^{\circ} \mathrm{C}$. The corrosion current density obtained for each temperature in succession are $260.12 \mathrm{~A} / \mathrm{cm}^{2} ; 299.73 \mathrm{~A} / \mathrm{cm}^{2} ; 310.76 \mathrm{~A} / \mathrm{cm}^{2} ; 334.24 \mathrm{~A} / \mathrm{cm}^{2} ;$ and 356.31 $\mathrm{A} / \mathrm{cm}^{2}$, while the value of CR (corrosion rate) is identified after entering the price of corrosion current density $\left(\mathrm{I}_{\text {cor }}\right)$ into the corrosion rate formula (Jones, 1991). Based on Fig. (6), with reference to the magnitude of the corrosion current density, the best corrosion resistance value is obtained if the nitriding process is carried out at 1.8 mbar for 3 hours at $350^{\circ} \mathrm{C}$. The worst corrosion resistance occurs when nitriding process is performed at 1.8 mbar for 3 hours at $500^{\circ} \mathrm{C}$.

Fig. (6) shows the results of ion nitriding at $350^{\circ} \mathrm{C}$. It appears that the curves in the passive area are flat. This phenomenon shows that the surface of nitriding process has a good corrosion resistance. At $400^{\circ} \mathrm{C}$ and $450^{\circ} \mathrm{C}$ the passive area curve lines look wavy which indicates a decrease in the corrosion resistance of the snippet. Then, the curve of potential versus $\log$ intensity of the current density of SS316L at $500^{\circ} \mathrm{C}$ and $550^{\circ} \mathrm{C}$ shows that curves in passive areas are wavy. This shows that the corrosion resistance of footage is getting worse. The worst corrosion resistance occurs at $550^{\circ} \mathrm{C}$.

Differences in corrosion resistance on samples after nitriding process are associated with phases formed during the nitriding process. They serve as protection layers. The results of EDS and XRD test samples show that metal nitride phase which was formed is Fe4N, CrN and $\beta$ phase $-\mathrm{Cr} 2 \mathrm{~N}$. Those decreased corrosion resistance of SS316L stainless steel. The higher the nitriding temperature processes is, the more the nitride metal phases are, but the corrosion resistance decreases. Generally, the corrosion resistant properties of AISI 316L stainless steel was obtained from the formation of a chromium oxide protective passive layer which is very stable and firmly attached to the surface, so it can protect the steel from corrosive surroundings. Nitriding processes done at higher temperatures showed disserve corrosion resistance properties because of chromium nitride phase formation. The lessening of chromium to form chromium nitride causes deficiency of chromium oxide on the surface which serves as protection layer against corrosive environment. Therefore, nitriding process at high temperature increases the number of nitride layers in the form of chromium nitride, and reduces corrosion resistance. 
a)

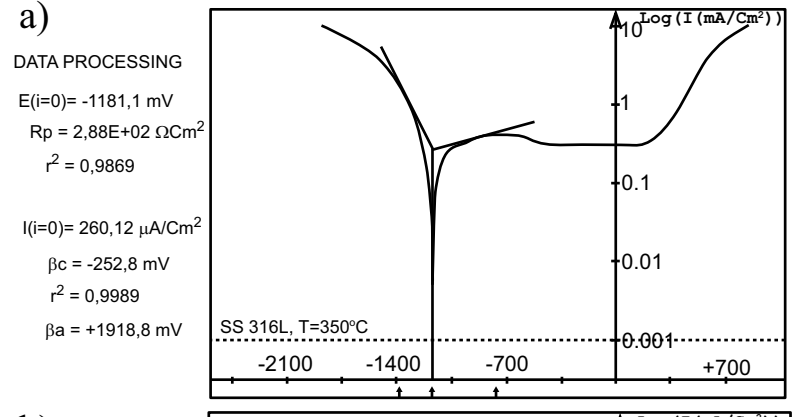

b)

DATA PROCESSING $E(i=0)=-1199,7 \mathrm{mV}$ $\mathrm{Rp}=2,34 \mathrm{E}+02 \Omega \mathrm{Cm}^{2}$

$r^{2}=0,9860$

$\mathrm{I}(\mathrm{i}=0)=299,73 \mu \mathrm{A} / \mathrm{Cm}^{2}$ $\beta \mathrm{c}=-250,6 \mathrm{mV}$ $r^{2}=0,9989$

$\beta a=+1266,3 \mathrm{mV}$

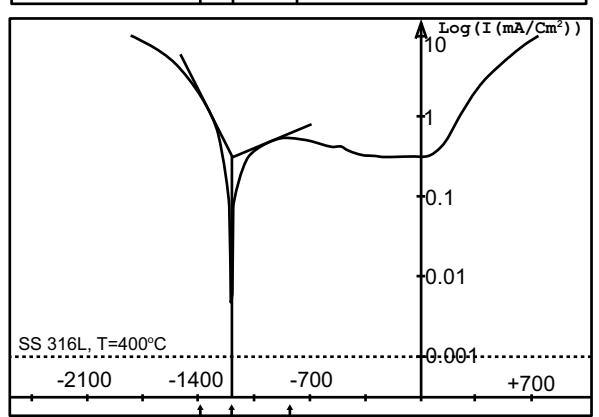

c)

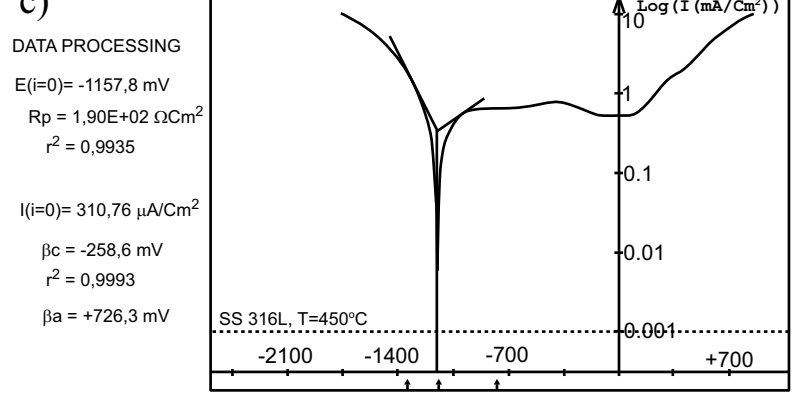

d)
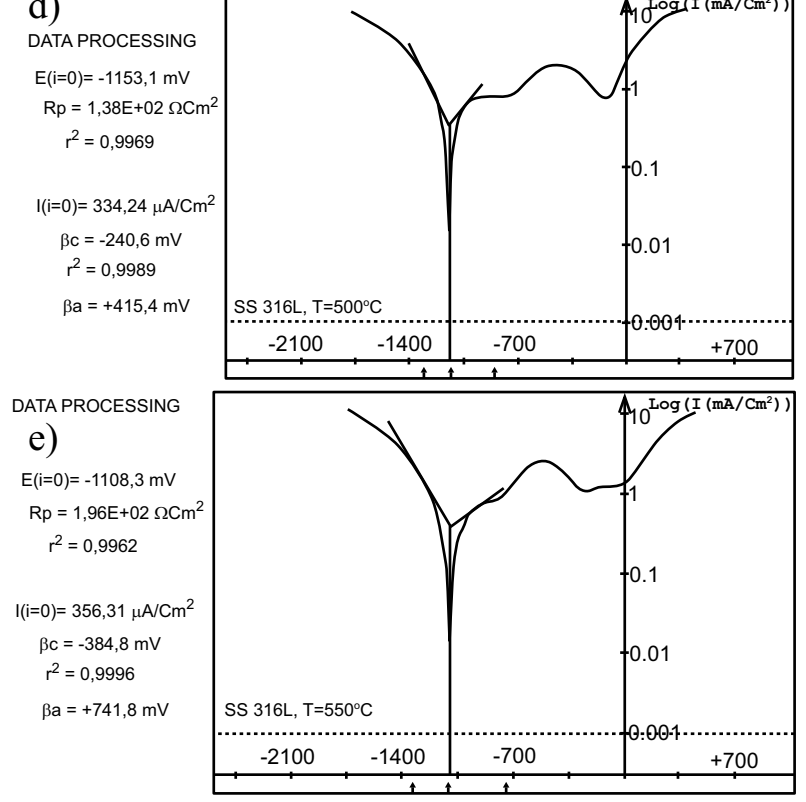

Fig. (6). Micrograph $\log$ intensity $v s$. potential corrosion current density footage of SS316L after nitriding process. (a) $350^{\circ} \mathrm{C}$, (b) $400^{\circ} \mathrm{C}$, (c) $450^{\circ} \mathrm{C}$, (d) $500^{\circ} \mathrm{C}$, and (e) $550^{\circ} \mathrm{C}$.

\section{CONCLUSION}

Plasma nitriding process increases corrosion resistance of biomaterial SS316L. Optimum corrosion resistance of SS 
$316 \mathrm{~L}$ stainless steel occurs at $350^{\circ} \mathrm{C}$ with increased corrosion resistance $33.98 \%$. It is caused by Fe4N, CRN and $\beta$ $\mathrm{Cr} 2 \mathrm{~N}$ phase which is formed on the surface of SS316L after plasma nitriding process.

\section{CONFLICT OF INTEREST}

The authors (editor) declare no conflict of interest, financial or otherwise.

\section{ACKNOWLEDGMENTS}

The authors are grateful to the Ministry of Research Technology and Higher Education of the Republic of Indonesia which has funded this research through 'Hibah Fundamental' Research Program.

\section{REFERENCES}

[1] Liu C, Yang D, Lin G, Min Q. Corrosion resistance and hemo compatibility of multilayered Ti/TiN - coated surgical AISI 316L stainless steel. Mater Lett 2005; 59: 3813-9.

[http://dx.doi.org/10.1016/j.matlet.2005.06.058]

[2] Forysthe J. Biomaterials, Department of Materials Engineering. Vic 3804: Monash University 2007; p. 3804.

[3] Bonfield W, Beheri JC, Doyle C, Bowman J, Abram J. Biomaterials and Biomechanics. Amsterdam: Elsevier 1984.

[4] Hansen DC. The Electrochemical Society Interface. 2008; 31-4.

[5] Mudali UK, Sridhar TM, Raj B. Corrosion of bio implants. Sadhana 2003; 28: 601-37. [http://dx.doi.org/10.1007/BF02706450]

[6] Oliveira, Revista Brasileira de Aplicacoes de Vacuo. 2003; 22: 63-6.

[7] Hermawan H, Ramdan D, Djuansjah JR. Metals for Biomedical Applications. Biomedical Engineering - From Theory to Applications 2011. [http://dx.doi.org/10.5772/19033]

[8] Dee KC, Puleo DA, Tos RB. Biomedical engineering. New York: Wiley and sons 2002.

[9] Ratner BO, Hoffmann AS, Schoen FJ, Lemons J, Eds. Biomaterials Science. San Diego, CA: Academic Press 1996. [http://dx.doi.org/10.1016/B978-012582460-6/50002-5]

[10] Suh H. Recent Advance in Biomaterials Yonsei Medical J 1998; 39(2): 87-96. [http://dx.doi.org/10.3349/ymj.1998.39.2.87]

[11] Alvarado J, Maldonado R, Marxuach J, Otero R. Biomechanics of hip and knee prostheses, aplication of engeneering mechanics in medicine. GED, University of Puerto Rico Mayaguez 2003.

[12] Mudali UK, Sridhar TM, Raj B. Corrosion of bio implants. Sadhana 2003; 28: 601-37. [http://dx.doi.org/10.1007/BF02706450]

[13] Larisch B, Brusky U, Spies H-J. Plasma nitriding of stainless steels at low temperatures. Surf Coat Tech 1999; 116-119: 205-11. [http://dx.doi.org/10.1016/S0257-8972(99)00084-5]

[14] Habibovic P, Barrère F, Blitterswijk CA, Groot KD, Layrolle P. J Am Ceram Soc 2002; 83: 517.

[15] Anandan C, William Grips, Ezhil Selvi V, Rajam KS. Effect of the temperature of plasma nitriding AISI 316L austenitic stainless steel, Revista Brasileira de Aplicacoes de Vacuo, vol. 22, pp. 63-66. 2007; 201: 7873-9.

[16] Lipin ski, Bielin ski P, Okro D, Jakubowski jW, Klimek W, Jagielski JL. Biomedical aspects of ion bombardment of polyethylene. Vacuum 2009; 83: 200-3.

[17] de Souza SD, Olzon-Dionysio M, Miola EJ, Paiva-Santos CO. Plasma nitriding of sintered AISI 316L at several temperatures. Surf Coat Tech 2004; 184: 176-81. [http://dx.doi.org/10.1016/j.surfcoat.2003.11.007]

[18] Rodríguez RJ, Medrano A, García JA, Fuentes GG, Martínez R, Puertolas JA. Improvement of surface mechanical properties of polymers by helium ion implantation, Surface \& Coatings technology, (2007), vol.201, pp.8146-8149

\section{(c) 2017 Kartikasari et al.}

This is an open access article distributed under the terms of the Creative Commons Attribution 4.0 International Public License (CC-BY 4.0), a copy of which is available at: (https://creativecommons.org/licenses/by/4.0/legalcode). This license permits unrestricted use, distribution, and reproduction in any medium, provided the original author and source are credited. 